\title{
Research on the achievement motivation levels of the amateur football players
}

\author{
İlimdar Yalçın ${ }^{1 a}$, Fehmi Çalık², Fikret Ramazanoğlu ${ }^{1}$, and Ömer Faruk Tutar ${ }^{3}$ \\ ${ }^{1}$ Department of Physical Education and Sport Teaching, Faculty of Sport Sciences, Sakarya \\ University, Turkey \\ ${ }^{2}$ Department of Recreation, Faculty of Sport Sciences, Sakarya University, Turkey \\ ${ }^{3}$ Department of Physical Education and Sport Teaching, Institute of Educational Sciences Sakarya \\ University, Turkey
}

\begin{abstract}
This study was conducted to determine the achievement motivation levels of the amateur football players based upon the importance of motivation on the athletes' successes. The research group comprises 243 voluntary amateur football players who actively participated in the competitions during 2016-2017 season in Elazig. In the study, "Sports-Specific Achievement Motivation Scale" that was developed by Willis (1982) and adapted to Turkish by Tiryaki and Godelek (1997) was used. The collected data were analyzed through SPSS 22 programme. The margin of error was accepted as $\mathrm{p}<0.05$. The cronbach alpha value was found as ,78. Consequently; when the subscales of achievement motivation of the amateur soccer players participating in the study were analyzed with some variables, it was found that there was a statistically significant difference between those aged 22-24 years and those aged 25-27 years in approach success. In the team playing year variable, the statistical significance was found between the ones who have 1 year football history in the team and those who are 5 years or more in the approach success. It was observed the approach to achievement motivation increased as the experience of playing for a team increased. As for the year of working with a trainer variable, it was found that there was a statistically significant difference between those who had 1 year past with coach and those who had 2 years past with the motivation to avoid failure.
\end{abstract} Keywords: Amateur, football, achievement, motivation

\section{Introduction}

Athletes generally want to keep their performance levels at the highest level, whether they are participating in training or participating. At this stage, the athlete sometimes faces both physical and psychological factors. Physical skills may be at the highest level in

${ }^{a}$ Corresponding author: ilimdaryalcin@gmail.com 
sports, however; if the athlete is psychologically inadequate, performance can not be successful. One of the most important factors affecting physical and psychological performance is motivation.

Motivation is to drive a person to work, to act and to inspire. Motivation can also be defined as "people behave with their own desires to achieve a specific purpose" [5].

The simplest way to understand motivation is to accept it as a process and divide it into the basic parts (needs, motivations, goals) that make up it [8]. Motivation can also be defined as the name of the process, which is influenced by one's motive and leads to sport activities depending on the current situations [4]. Motivation is also directly related to learning experiences, different personality traits, environmental factors, and physical wellbeing [2].

One of the most misunderstood areas of motivation is the sports. The reasons for this can be listed as follows:

-Motivation is often confused by the coaches with the concept of arousal or activation. Before the match or training, it is wrong to consider that talking to the team at the meeting, talking about the game etc. are motivated athletes.

-A second concept mixed with motivation is positive thinking. Expressing the long working hours of the team may provide a positive impression of being a team based on talented athletes, but it does not provide motivation [9].

The relationship between the power of motivation and success is very important, especially in the sports environment. If the motive power is low, it is sure to result in a low success. Every individual tends to being in peaceful situations and avoiding in disturbing situations. Orientation and avoidance situations are present in the structure of the instigators. If which tendency is more severe, motives belong to it is emerge. According to this, while success is driven by success or avoidance of failure, friendship motivation occurs in the search for reputation or avoiding rejection [8].

Motivation in sport is gathered under two different themes. First of them are the orientation of the purpose of fulfilling a certain task and improving the talent and competence of the person; the second is the ego orientation, which demands motivation to perform better and be better than other factors [3].

In sports achievement motivation, the immediate vicinity of the athlete usually plays a decisive role in his or her expectation level. The athlete, who can pass on to the athletes who are shown competitors to him/her, would not be satisfied if he could not choose the standards for his/her success and could not put them because she/he can not develop a feeling beyond whose vicinity wants. Every athlete who wants to be successful develops a qualification scale for himself. When the athlete passes or reaches the limits of his superior achievement, he may not make much efforts to achieve it. The athlete balances himself / herself with the fear of failure and the achievement prospect [7].

The studies on the concept of motivation for success from the psychological factors which are important influences on the performance situation in the sports environment are frequently discussed both our country and the international arena. It is thought that the investigation of this concept will contribute to both the psychological and physical qualities of the coaches and the athletes in the contest or competition environment in the positive direction. In this respect, the aim of this study is to examine the motivation level of success of the athletes playing football in amateur leagues.

\section{Method}

The research is a descriptive model for determining the motivation level of amateur soccer players and is in the relational screening model. 


\subsection{Research group}

The research group consists of 248 volunteer athletes who are actively play football in amateur clubs in Elazig during the 2016-2017 season. The 248 data obtained were not processed because 5 data did not show normal distribution. Therefore, the research group based on the study was designated as 243 .

\subsection{Data collection tools}

In the research, "Sports Specific Achievement Motivation Scale" developed by Willis (1982) was used [12]. The scale consists of a total of 40 items and the items are of the fivepoint likert type, expressed as "never", "very little", "sometimes", "pretty much" and "always". The scale consists of three sub-dimensions. These; 12 items $(1,3,5,7,9,10,11,13,21,29,30,35)$ related to power motive, 17 items $(4,6,8,12,16,18,19,20,23,24,26,31,32,33,36,38,39)$ related to motive to approach success and 11 items $(2,14,15,17,22,25,27,28,34,37,40)$ related to motive to avoid failure. The validity and reliability studies of your scale were made on 996 university and high school students. For three subscales, the alpha reliability coefficient was between $r=0.76$ and 0.78 , and the test repeatability reliability coefficient was between $r=0.69$ and 0.75 . The scale adapted to Turkish athletes by Tiryaki and Gödelek (1997). As a result of the reliability analyzes conducted by Tiryaki and Gödelek (1997), alpha reliability coefficients were found as $r=0,81$ for the power motive subscale, $r=0,82$ motive to approach success subscale and $\mathrm{r}=0,80$ for the motive to avoid failure [9].

\subsection{Analysis of the data}

The data obtained in the study were taken from the SPSS 22 package program and the frequency (f) and percent (\%) distributions of the variables were calculated. The histograms were checked by evaluating skewness and kurtosis to ensure normal distribution of the data. Therefore, the t-test and variance analysis (Anova) test was used. Tukey test results were used to determine which groups differed in meaningful differences. The margin of error in the study was taken as $\mathrm{p}<0.05$. The cronbach alpha value of the study was found as 0,78 .

\section{Findings}

In this section, findings about variables of study are included. The findings showing the distribution of amateur football players according to their personal qualities were analyzed and interpreted. 
Table 1. Sports specific achievement motivation according to age variation of amateur footballers statistical distribution values related to the level of sub-dimensions

\begin{tabular}{|l|l|c|c|c|c|c|}
\hline & Age & $\mathbf{N}$ & $\overline{\mathbf{X}}$ & $\mathbf{S d}$ & $\mathbf{F}$ & $\mathbf{p}$ \\
\hline \multirow{4}{*}{ Power } & $16-18$ & 23 & 45.21 & 6.47 & & \\
Motive & $19-21$ & 95 & 43.30 & 5.23 & & \\
& $22-24$ & 35 & 42.60 & 5.48 & 1.41 & 0.23 \\
& $25-27$ & 34 & 44.32 & 5.46 & & \\
& 28 and over & 56 & 44.83 & 6.63 & & \\
& Total & 243 & 43.88 & 5.79 & & \\
Approach & $16-18$ & 23 & 68.26 & 5.20 & & \\
Success & $19-21$ & 95 & 68.64 & 5.90 & & \\
& $22-24^{*}$ & 35 & 66.51 & 6.98 & 3.05 & $0.01^{*}$ \\
& $25-27^{*}$ & 34 & 71.11 & 3.55 & & \\
\hline \multirow{5}{*}{ Avoid to } & 28 and over & 56 & 68.78 & 4.83 & & \\
Failure & Total & 243 & 68.67 & 5.60 & & \\
& $16-18$ & 23 & 38.95 & 5.13 & & \\
& $19-21$ & 95 & 39.57 & 6.75 & & \\
& $22-24$ & 35 & 39.45 & 6.38 & \multirow{2}{*}{0.09} & 0.98 \\
& $25-27$ & 34 & 39.50 & 6.76 & & \\
\hline
\end{tabular}

*Level of meaningful difference determined as $\mathrm{p}<0.05$.

When the analysis results of the level of success motivation sub-dimensions specific to the age of the amateur football players participating in the study in table- 1 are examined, a statistically significant difference was found between those in the age range of 22-24 years and those in the range of 25-27 years in the success approach motivation sub-dimension $(\mathrm{p}<0.05)$.

Table 2. Statistical distribution values related to the level of sports specific achievement subdimensions according to the yearly variable of amateur football players playing in the team

\begin{tabular}{|l|l|c|c|c|c|c|}
\hline & $\begin{array}{l}\text { Year of the Play } \\
\text { Football in Team }\end{array}$ & $\mathbf{N}$ & $\overline{\mathbf{X}}$ & $\mathbf{S d}$ & $\mathbf{F}$ & $\mathbf{p}$ \\
\hline \multirow{5}{*}{ Power } & 1 year & 62 & 42.59 & 5.58 & & \\
Motive & 2 years & 52 & 43.78 & 5.10 & & \\
& 3 years & 40 & 44.30 & 7.07 & 1.22 & 0.30 \\
& 4 years & 30 & 44.40 & 5.59 & & \\
& 5 and over & 59 & 44.76 & 5.66 & & \\
& Total & 243 & 43.88 & 5.79 & & \\
\hline \multirow{5}{*}{ Approach } & 1 year* & 62 & 66.82 & 6.64 & & \\
Success & 2 years & 52 & 68.67 & 4.84 & & \\
& 3 years & 40 & 69.22 & 5.64 & 2.65 & $0.03^{*}$ \\
& 5 years & 30 & 69.56 & 4.99 & & \\
& Total & 59 & 69.81 & 4.94 & & \\
Avoid to & 1 year & 243 & 68.67 & 5.60 & & \\
Failure & 2 years & 62 & 37.95 & 7.13 & & \multirow{2}{*}{0.17} \\
& 3 years & 52 & 40.48 & 6.47 & & \\
& 4 years & 40 & 41.15 & 6.87 & 1.61 & \\
& 5 and over & 30 & 39.60 & 5.56 & & \\
& Total & 59 & 39.44 & 7.50 & & \\
\hline
\end{tabular}

*Level of meaningful difference determined as $\mathrm{p}<0.05$. 
When the analysis results of the level of the sport-specific success motivation subdimensions according to the variable year of playing in team amateur football players participating in the study in table- 2 are examined, it was found that there was a statistically significant difference between the playing 1 year and 5 years and over in approach success $(\mathrm{p}<0.05)$.

Table 3. Statistical distribution values regarding sports-specific achievement motivation subdimension levels by amateur footballer's yearly variable of coaching work

\begin{tabular}{|c|c|c|c|c|c|c|}
\hline & $\begin{array}{l}\text { Years of Woking } \\
\text { with Coach }\end{array}$ & $\mathbf{N}$ & $\bar{X}$ & Sd & $\mathbf{F}$ & $\mathbf{p}$ \\
\hline \multirow{6}{*}{$\begin{array}{l}\text { Power } \\
\text { Motive }\end{array}$} & 1 year & 86 & 43.73 & 5.94 & \multirow{6}{*}{1.09} & \multirow{6}{*}{0.35} \\
\hline & 2 years & 41 & 43.24 & 4.50 & & \\
\hline & 3 years & 54 & 43.14 & 4.92 & & \\
\hline & 4 years & 30 & 45.06 & 4.98 & & \\
\hline & 5 years and over & 32 & 45.21 & 8.30 & & \\
\hline & Total & 243 & 43.88 & 5.79 & & \\
\hline \multirow{6}{*}{$\begin{array}{l}\text { Approach } \\
\text { Success }\end{array}$} & 1 year & 86 & 67.61 & 6.16 & \multirow{6}{*}{1.28} & \multirow{6}{*}{0.27} \\
\hline & 2 years & 41 & 68.90 & 5.20 & & \\
\hline & 3 years & 54 & 69.20 & 5.58 & & \\
\hline & 4 years & 30 & 69.50 & 3.86 & & \\
\hline & 5 years and over & 32 & 69.59 & 5.81 & & \\
\hline & Total & 243 & 68.67 & 5.60 & & \\
\hline \multirow{6}{*}{$\begin{array}{l}\text { Avoid to } \\
\text { Failure }\end{array}$} & 1 year* & 86 & 37.93 & 7.11 & \multirow{6}{*}{3.48} & \multirow{6}{*}{$0.00 *$} \\
\hline & 2 years* & 41 & 42.12 & 5.82 & & \\
\hline & 3 years & 54 & 39.48 & 6.58 & & \\
\hline & 4 years & 30 & 41.66 & 4.79 & & \\
\hline & 5 years and over & 32 & 39.00 & 8.60 & & \\
\hline & Total & 243 & 39.58 & 6.91 & & \\
\hline
\end{tabular}

*Level of meaningful difference determined as $\mathrm{p}<0.05$.

When the results of analysis of the level of success motivation subspecific according to the variation of year of coach working with amateur soccer players participating in the study in table- 3 were examined, It was observed that there was a statistically significant difference between the ones who worked 1 year and those who worked for 2 years.with the coach in the failure avoidance motivation subscale $(\mathrm{p}<0.05)$.

\section{Discussion and conclusion}

In this section, the findings about whether the sub-dimensions of the sport-specific success motivation of 243 amateur soccer players participating in this study differ according to some variables are discussed and interpreted.

When the results of amateur soccer players' age variable and sport - specific success motivation sub - dimensions were examined, a statistically significant difference was found between those in the 22-24 age range and those in the 25-27 age range in the success approach motivation subscale $(\mathrm{p}<0.05)$. It was found to be a favorable difference between age 25-27. It has been observed that older footballers have a higher level of approaching success than younger ones. This confirms that the age factor is directly related to experience. When different studies are examined; it is observed that there is a statistically significant relation between age and power motive in a study on sport-specific success motivation made to the sportsmen participating in the summer school sports made by Ustun et al. . Although there is no significant difference in approach to achievement subscale, we found that older adults had higher levels of motivation to approach success than younger 
ones [11]. It has been determined by Mladenovic et al. hat there is a statistically significant difference in age level between young athletes and non-athletes in relation to their ability to show individual strength and achievement motivation, and to show a decisive effect [6].

When the results of amateur soccer players' variation of current team playing years and sport-specific success motivation sub-dimensions are examined, it is determined that there is a statistically significant difference between the ones who played in the current team and those who played 5 years in the approach motivation sub-dimension $(\mathrm{p}<0.05)$. It has been observed that there is a meaningful difference in favor of soccer players who played in the current team for more than 5 years. It has been found that as the number of years of team play increases, it also steadily increases at the level of approaching success. It can be said that the approach of the athletes to the success and the increase of their performance are related to the duration of the team and get to know team well. When a different study result is examined, there is no statistically difference between the duration of playing in the team and the sport-specific success motivation sub-dimensions in a study on motivational factors affecting team performance by Ural [10]. However, although there is no difference, as the number of years of playing in the current team increases, it has been observed that there is an impetus to approach success and an impetus to avoid failure [10]. In this respect, Ural's work shows smilarity with our study [10].

When the results of amateur soccer's woking years with current coach and sportspecific success motivation sub-dimensions are examined, it was observed that there was a statistically significant difference between the ones who worked 1 year and those who worked for 2 years.with the coach in the failure avoidance motivation subscale $(p<0.05)$. The difference was found to be favorable to the current coach who has been working for 2 years. It has been observed that the level of motivation for avoiding unsuccessful athletes who have started to work with the current coach is very low. This indicates that the athletes who started to work with a new coach are related to the period of adaptation team and coach. When different studies are examined; in a study conducted by Yalcin in order to examine the motivations of success of hearing-impaired futsal athletes, it was determined that there is a statistically significant relationship between the current coach working year variant and the approach to success. As the number of years of work with the current coach increased, the level of approach to success increased [13]. Similarly, in a study conducted by Abakay on the relation of footballer and coach communication with success motivation of footballers of different statutes, it was determined that there is no statistically difference between the subscales of success motivation specific to sport and the current coach working year variable. However, it was observed that the level of motivation for avoidance of unsuccessful athletes with low working years with current coach was low. Although it did not differ, it was observed that the level of motivation for avoidance of failure athletes with low working years with current coach was low [1].

As a result; Statistically significant results were found between the age variable of amateur soccer players participating in the study and the level of motivation to approach success. It has been observed that older athletes tend to approach success more than young athletes. It has been determined that there is a statistically significant difference between playing in the current team year variance and the approach to success. As the number of years of playing in the current team increased, it was observed that the level of approach to success increased proportionally. When we look at the variation of yearly work with current coach, It was observed that there was a statistically significant difference between the motive to avoid failure and the current coach and working years.

Regarding the results of the study the following recommendations are made:

-As playing time of amateur football players increase their approach to success also increase in a proportional way. That is why it is reccomended to coaches and club menagers to make long-time period aggrements with football players. 
-As working time increase between amateur football players and coaches while their approach to success increase, their avoid to failure reduce. So it is suggested that a coach has to be employed in a club for a long-term period.

\section{References}

1. Abakay, U. Futbolcu-antrenör iletişiminin farklı statülerdeki futbolcuların başarı motivasyonuyla ilişkisi. Gazi Üniversitesi, Sağlık Bilimleri Enstitüsü, Beden Eğitimi ve Spor Anabilim Dal1, Doktora Tezi, Gaziantep, 76, (2010)

2. Barrett, D.W., Patock-Peckham, J.A., Hutchinson, G.T. \& Nagoshi, C.T. Cognitive 19. motivation and religious orientation. Personality and Individual Differences, 38, 461-74 (2005)

3. Hutzler, Y., Oz, M., Barak S. Goal perspectives and sport participation motivation of special olympians and typically developing athletes. Research in Developmental Disabilities, 34, 2149-2160 (2013)

4. İkizler, C. Sporda başarıyı etkileyen psikolojik faktörler. Alfa Basım Yayım Dağıtım, İstanbul, 47, (1994)

5. Koçel, T. İşletme Yöneticiliği. Beta Yayınları, İstanbul, 633-653, (2003)

6. Mladenovic, M., Lazarevic, P., Trunic N., Bogavac, D. \& Zivkovic, M. Differences in personality features and achievement motivation in child athletes and non-athletes. Facta Universitatis, Series: Physical Education and Sport, 14, 3, 415 - 425 (2016)

7. Mungan, S. Sporda motivasyon faktörü olarak ödül ve ceza. Marmara Üniversitesi, Sağlık Bilimleri Enstitüsü, Beden Eğitimi ve Spor Anabilim Dalı, Yüksek Lisans Tezi, İstanbul, p.75, (1995)

8. Soyer, F., Can, Y., Güven, H., Hergüner, G., Bayansalduz, M. \& Tetik, B. Sporculardaki başarı motivasyonu ile takım birlikteliği arasındaki ilişkinin incelenmesi. Uluslararası İnsan Bilimleri Dergisi, 7, 1, 225-239 (2010)

9. Tiryaki, Ş. \& Gödelek, E. Spora özgü başarı motivasyonu ölçeğinin türk sporcuları için uyarlanması çalışması. I. Uluslararası Spor Psikolojisi Sempozyumu Bildiri Kitapçığı, Bağırgan Yayınevi, Ankara, pp.128-141 (1997)

10. Ural, O. Futbolda takım performansına etki eden motivasyonel faktörlerin belirlenmesine yönelik bir uygulama (Gençlerbirliği spor kulübü örneği). Gazi Üniversitesi, Sağlık Bilimleri Enstitüsü, Beden Eğitimi ve Spor Anabilim Dalı, Yüksek Lisans Tezi, Gaziantep, p.59 (2008)

11. Üstün, Ü.D., Acet, M. \& Ersoy, A. Sporcular için spora özgü başarı motivasyonu. Yaz Spor Okulundan Bir Örnek. Sosyal Bilimler Dergisi, 49, 114-123 (2016)

12. Willis, J.D. Three Scales to Measure Competition-related Motives in Sports. Jaurnal of Sport Psychology, 338-353 (1982)

13. Yalçın, İ. İşitme engelli futsal sporcularının başarı motivasyon düzeylerinin incelenmesi. Fırat Üniversitesi, Sağlık Bilimleri Enstitüsü, Beden Eğitimi ve Spor Anabilim Dalı, Yüksek Lisans Tezi, Elazı̆g, p.71 (2015) 